Stanisław Janeczek

Katolicki Uniwersytet Lubelski im. Jana Pawła II e-mail: janeczek@kul.lublin.pl

\title{
Kontekst filozoficzny dydaktyki przyrodoznawstwa w szkołach Komisji Edukacji Narodowej
}

DOI: http://dx.doi.org/10.12775/RF.2017.002

Tak częste wśród historyków filozofii skupienie się na oryginalnych dokonaniach filozoficznych, ocenianych zwykle w perspektywie współczesnego nam postrzegania dziejów filozofii, jest źródłem częstego utożsamiania specyfiki tych dokonań z paradygmatem podzielanym przez większość filozofów danego okresu. Wgląd w ten paradygmat umożliwia jednak dopiero analiza dydaktyki szkolnej, która asymilowała ostrożnie filozoficzne i naukowe nowinki. Nie inaczej jest z kulturą filozoficzną oświecenia ocenianą zwykle w aspekcie przemian ideowych (światopoglądowych), zwłaszcza gdy widzi się w nich obecnie bodaj zasadniczy fundament Unii Europejskiej, o czym świadczą dyskusje dotyczące jej Karty praw podstawowych ${ }^{1}$. Tłumaczy to m.in. popularność historiozoficznych wizji Jonathana Israela, który eksponuje naturalistyczny wymiar kultury oświecenia, a zwłaszcza rolę tzw. „oświecenia radykalnego", jako nurtu materialistycznego i republikańskiego, właści-

1 Zob. A. Banaszkiewicz, Karta praw podstawowych jako "uwieńczenie" unijnego systemu ochrony praw człowieka, "Studia Erasmiana Wratislaviensia”, 2010, z. 4, s. 175-193; M. Piechowiak, Aksjologiczne podstawy "Karty praw podstawowych" Unii Europejskiej, „,Studia Prawnicze”, 2003, nr 1(155), s. 5-29. 
wego rewolucji francuskiej². Popularność tej wizji stymuluje dominacja naturalizmu we współczesnej filozofii nauki ${ }^{3}$.

Kultura oświecenia, wieku programowo eklektycznego, była zjawiskiem złożonym, i to nie tylko $\mathrm{w}$ aspekcie ideowym ${ }^{4}$. Złożona była także ówczesna kultura naukowa, gdyż tylko częściowo wyzwalała się z uwikłań filozoficznych, przy czym filozofia dalej stanowiła zwieńczenie działalności naukowej. Oświecenie kontynuuje bowiem ideał maksymalistycznie, a nawet autonomicznie pojętej filozofii, choć rzeczywiście coraz bardziej zmienia się paradygmat naukowości, wyznaczany przez wieki przez filozofię, która stara się w wieku XVIII coraz powszechniej podążać za ideałem empirycznie zorientowanego przyrodoznawstwa. Podejście to uwidacznia się w praktyce naukowej wybitnego i wpływowego matematyka i fizyka, jakim był Jean Le Rond d'Alembert, dla którego filozofia dalej ma scalać, a nawet uzupełniać ogniwa całościowej wizji świata 5 . W obrębie nauki pojętej wciąż jako system filozofii jest bowiem miejsce nie tylko na ",wiadomości pewne”, ,opatrzone piętnem oczywistości", do których należą nauki matematyczne, o charakterze abstrakcyjnym, stanowiące fundament matematyki stosowanej, a więc algebra, geometria i mechanika, analizujące najogólniejsze własności ciał. Uprawnione są jednak także prawdy stanowiące fundamentalne tezy tradycyjnej filozofii, czyli „idea nas samych, prowadząca do idei Bytu Wszechmocnego i zasadniczych naszych obowiązków"6. Stąd też w tak pojętej filozofii znajdzie się - zdaniem d'Alemberta - miejsce i na elementy metafizyki pojętej tradycyjnie, również bowiem wątki ontologiczne („własności ogólne bytów... istnienie, możliwość, trwanie,

2 J. Israel, A Revolution of the Mind. Radical Enlightenment and the Intellectual Origins of Modern Democracy, Princeton University Press, Princeton, NJ, 2009; idem, Democratic Enlightenment. Philosophy, Revolution, and Human Rights, 1750-1790, Oxford University Press, Oxford 2011. Zob. P. Gut, Radykalne Oświecenie i nowoczesność, w: Znaczenie filozofii Oświecenia. Człowiek wśród ludzi, red. B. Grabowska, A. Grzeliński, J. Żelazna, Wydawnictwo Naukowe UMK, Toruń 2016, s. 91-102; S. Janeczek, Rola oświecenia chrześcijańskiego w kulturze wieku XVIII, „Kultura i Wartości”, 2015, nr 15, s. $9-48$.

3 Por. G. Bugajak, Problem naturalizmu w dialogu nauki i religii, w: Filozofia przyrody, red. S. Janeczek, A. Starościc, D. Dąbek, J. Herda, Wydawnictwo KUL, Lublin 2013, s. 301-320; D. Sagan, Teoria inteligentnego projektu - argumenty za i przeciw, w: ibidem, s. 335-383.

4 Zob. R. Butterwick-Pawlikowski, Między Oświeceniem a katolicyzmem, czyli o katolickim oświecenia i oświeconym katolicyzmie, „Wiek Oświecenia”, t. 30, 2014, s. 15-17.

5 Zob. S. Janeczek, Z dziejów kultury naukowej. Koncepcja nauki Jean le Rond d'Alemberta, „Roczniki Kulturoznawcze”, t. 4, 2013, nr 1, s. 59-92.

6 J. le Rond d'Alembert, Discours préliminaire de l'Encyclopédie, w: CEuvres complètes de d'Alembert, red. A. Belin, t. 1-5, Paris 1821-1822; repr. Slatkine, Genève 1967, t. 1, s. 29-30; idem jako: Wstęp do "Encyklopedii", przekł. J. Hartwig, PWN, Warszawa 1954, s. 25. 
substancja, atrybut"), trudno więc jednoznacznie traktować jako przejaw „prepozytywizmu”. Nic dziwnego, że d'Alembert podtrzymywał ograniczony wykład metafizyki pojętej jako racjonalny fundament światopoglądu chrześcijańskiego, np. uzasadniając istnienie Boga, choćby postawa ta nie była zawsze zgodna $\mathrm{z}$ zasadami swoistego getta nowożytnego empiryzmu?

Nie zaskakuje więc, że Wielka encyklopedia filozofii, której sekretarzem naukowym był d'Alembert, w haśle Philosophie respektuje osiągnięcia filozofii pojętej klasycznie, a więc obejmującej jej wszystkie dyscypliny, także wiążące filozofię ze światopoglądem ${ }^{8}$. Dlatego też podstawowym punktem odniesienia wizji filozofii podtrzymywanej przez Encyklopedie jest dokonanie Christiana Wolffa, obejmujące zarówno filozofię teoretyczna, czyli w istocie metafizykę, jak i filozofię praktyczna, odpowiednio do dwu obszarów ludzkich działań, w postaci logiki i filozofii moralnej. Choć autorowi hasła Filozofia nade wszystko bliski jest kult faktów, ujmowanych na drodze obserwacji i eksperymentów, to nie ogranicza się do postulatu ich prostej rejestracji, ale wymaga sformułowania „un systême complet", jak np. w refleksji kosmologicznej Noël-Antoine de Pluche'a9. Nie przekreśla to właściwego „bon esprit”, utożsamiane-

7 Idem, Discours préliminaire de l'Encyclopédie, w: CEuvres complètes de d'Alembert, t. 1, s. 103; idem, Wstęp do Encyklopedii, s. 140. Zob. S. Janeczek, Prepozytywizm filozofii Jean le Rond d'Alemberta?, "Zeszyty Naukowe KUL", t. 55, 2012, nr 2(218), s. 3-24. Por. idem, Przejawy refleksji metafizycznej w filozofii Étienne'a Bennota de Condillaca (1715-1780), w: Z dziejów filozoficznej refleksji nad człowiekiem. Księga pamiatkowa ku czci Profesora Jana Czerkawskiego (1939-2007), Redakcja Wydawnictw KUL, Lublin 2007, s. 257-274.

8 Encyclopédie ou dictionnaire universel raisonné des sciences, des arts et des métiers, par une société de gens de lettres. Mis en ordre et publié par... [Denis] Diderot et quant à la partie mathématique par... ... [Jean le Rond] D'Alembert, t. 1-35, Paris 1751-1780; reprint F. Frommann Verlag, Stuttgart 1966-1995, t. 12, s. 511-515. Odbiciem tej maksymalistycznie pojętej wizji filozofii, łączącej doktrynę ze specyficznym (wymagającym) stylem życia filozofa, jest w Encyklopedii hasło Philosophe, które formułuje wizję filozofa, będącą synonimem postawy racjonalnej w każdej dziedzinie działania i zachowań. Filozof winien unikać emocji i nieuporządkowanej wyobraźni, opierać osąd na dogłębnym i rozważnym sądzie, ugruntowanym na obserwacji, ale także dążyć dalej do odkrycia przyczyn. Powinien też potrafić precyzyjnie określać wartość swoich przekonań. W: Encyclopédie ou dictionnaire universel raisonné, t. 12, s. 509-511.

9 Histoire du ciel où l'on recherche l'origine de l'idolâtrie et les méprises de la philosophie sur la formation et sur les influences des corps célestes, t. 1-2, Paris 1711-1740². Pluche był bardzo popularnym autorem ze względu na publikację dziewięciotomowego dzieła Le spectacle de la nature, ou Entretiens sur les particularités de l'histoire naturelle, qui ont paru les plus propres à rendre les jeunes-gens curieux, E à leur former l'esprit, t. 1-8 (tom ostatni ma dwa wolumeny), Paris $1732-1752^{2}$. Dzieło to, przełożone aż na dziewięć języków, zespala apologetycznie najnowszą fizykę Newtona z biblijną wizją kosmologii. Pluche oponuje przeciwko "romans philosophiques”, a tym bardziej przeciw wizjom poetycko-religijnym, $\mathrm{w}$ to miejsce postuluje zespolenie wykładu historii naturalnej i eksperymentalnej fizyki. Zob. S. Janeczek, Filozofia w „Wielkiej Encyklopedii 
go z "esprit philosophique”10, który obejmuje właściwą Condillacowi krytykę ducha systemów, także właściwego metafizycznym systemom powstałym $\mathrm{w}$ wieku $\mathrm{XVII}^{11}$, rzetelnie ujęte syntezy mają być bowiem zawsze ugruntowane na danych faktualnych zaczerpniętych z przyrodoznawstwa, odpowiednio do zaleceń metodologicznych oświeceniowych przyrodników, takich jak Georges-Louis Leclerc de Buffon czy Charles Bonnet ${ }^{12}$.

Zmiany, które dokonały się w kulturze naukowej, uwidoczniły się w ówczesnej oświacie. W wieku XVIII przeszła ona długą drogę, od humanistyczno-filozoficznego szkolnictwa po model w jakiejś mierze odpowiadający standardom współczesnych reform szkolnych ${ }^{13}$. W połowie wieku XVIII absolutystyczna władza państwowa zacznie przejmować szkolnictwo, które pozostawało w rękach instytucji wyznaniowych. Zespalało ono religijno-moralistyczny model wychowania z ukonstytuowanym od renesansu modelem kształcenia językowo-humanistycznego $^{14}$. Szkoła ta była wyrazem kultury autorytetu, utożsamiającej studium o świecie z lekturą tekstów starożytnych, na zasadzie zaznajamiania z nowymi treściami przez rozumiejące poszerzanie słownictwa ${ }^{15}$. W formie systematycznej wiedzę o świecie czerpano ze studium filozofii w postaci tzw. nowożytnego arystotelizmu chrześcijańskiego, zwanego drugą scholastyka, wieńczącego nauczanie ogólnokształcące. Dopiero w połowie wieku XVIII do obowiązkowego curriculum szkolnego są wprowadzane elementy kształcenia matematyczno-przyrodniczego, odpowiadającego pełniej potrzebom ówczesnej gospodarki czy wojska ${ }^{16}$.

Francuskiej", w: Z badań nad filozofią XVII wieku, jej źródłami i kontynuacjami, red. H. Jakuszko, Lubelskie Towarzystwo Naukowe, Lublin 2013, s. 157-170.

10 Kawaler Jacourt (sygnowany jako „D.J”) Esprit philosophique, w: Encyclopédie ou dictionnaire universel raisonné, t. 12, s. 515. Por. CEuvres complètes de d'Alembert, t. 1, s. 78-79; idem, Wstęp do Encyklopedii, s. 100-102.

11 Zob. É. Condillac, Traité des systèmes, w: CEuvres philosophiques de Condillac, t. 1, red. G. Le Roy, Presses universitaires de France, Paris 1947, s. 204-217. Por. z dokumentacją S. Janeczek. Logika czy epistemologia? Historycznofilozoficzne uwarunkowania nowożytnej koncepcji logiki, Wydawnictwo KUL, Lublin 2003, s. $501 \mathrm{nn}$.

12 Zob. A. O. Lovejoy, Wielki łańcuch bytu. Studium z dziejów idei, przekł. A. Przybysławski, „KR”, Warszawa 1999, s. 213-336.

13 Zob. S. Janeczek, Wspótczesna reforma nauki i szkolnictwa wyższego w perspektywie historycznej, "Communio", t. 33, 2013, nr 2(182), s. 116-139.

14 Zob. idem, Szkoła jezuicka a szkoła renesansowa. Regres czy twórcza kontynuacja?, „Rocznik Wydziału Pedagogicznego Wyższej Szkoły Filozoficzno-Pedagogicznej Ignatianum w Krakowie", 2005, s. 191-208; idem, Elementy humanizmu renesansowego w szkole jezuickiej, w: Renesansowy ideat chrześcijanina, red. W. Sajdek, Wydawnictwo KUL, Lublin 2006, s. 299-333.

15 Zob. idem, Edukacja oświeceniowa a szkoła tradycyjna. Z dziejów kultury intelektualnej i filozoficznej, Wydawnictwo KUL, Lublin 2008, s. 15-131.

16 Zob. idem, Geneza nowożytnego arystotelizmu chrześcijańskiego, w: Oblicza filozofii XVII wieku, red. S. Janeczek, Wydawnictwo KUL, Lublin 2008, s. 477-512. 
Oświeceniowy duch reform ujawnił się od połowy wieku XVIII także w Rzeczpospolitej Obojga Narodów, zwłaszcza w szkołach prowadzonych przez pijarów i jezuitów. Do dwu- czy trzyletniego kursu scholastycznej filozofii włączono wówczas elementy nowożytnej filozofii, a zwłaszcza przyrodoznawstwa. Analogicznie jak na oświeceniowych uniwersytetach europejskich, mniej więcej od połowy wieku XVIII zaowocowało to nurtem określanym jako philosophia recentiorum, eklektycznie asymilującym osiągnięcia nowożytnej kultury filozoficznej i naukowej (przyrodniczej). Dbano jednak o zachowanie ortodoksji religijnej, w duchu tzw. oświecenia chrześcijańskiego, zastępując nowożytny arystotelizm chrześcijański ${ }^{17}$.

Kasata jezuitów wymusiła także w Rzeczpospolitej przejęcie szkół prowadzonych przez ten zakon i powstanie KEN, urzeczywistniając eudajmonistyczno-utylitarystyczne i obywatelskie ideały oświecenia oraz tradycyjne wzorce religijne, moralne i narodowe ${ }^{18}$. Równocześnie KEN usiłowała odejść od jednostronności kształcenia językowego i filozoficznego. $\mathrm{Z}$ tradycyjnego wykładu filozofii pozostawiła bowiem w szkole średniej tylko logikę i elementy praksistycznie rozumianej „nauki moralnej", a prawo naturalne na uniwersytetach. Podkreśliła natomiast znaczenie matematyki, traktowanej jako cenne narzędzie w kształceniu praktycznych umiejętności myślenia logicznego i niezbędne instrumentarium fizyki. Nade wszystko ceniła przyrodoznawstwo, usamodzielniając je ze studium filozofii $\mathrm{w}$ formie osobnych przedmiotów, choć $\mathrm{z}$ trudnościami wynikającymi z kształtowania się dopiero wielu uznanych współcześnie dyscyplin, np. chemii traktowanej jako integralny element fizyki lub nauka samodzielna, użyteczna zwłaszcza dla studium mineralogii jako elementu trzyczęściowej historia naturalis, obejmującej nadto królestwo roślin i zwierząt. Obok przedmiotów biologicznych, postrzeganych początkowo przede wszystkim w perspektywie gospodarki rolnej, KEN ceniła fizykę, powiązaną zgodnie z ówczesnymi standardami z mechanika, jako najwyżej zaawansowany metodologicznie przejaw przyrodoznawstwa empiryczno-matematycznego, od czasów Izaaka

17 Idem, Ideały wychowawcze $i$ dydaktyczne w szkolnictwie pijarskim a "oświecenie chrześcijańskie”. Próba syntezy, „Nasza Przeszłość”, t. 49, 1994, nr 82, s. 115-161; idem, Czym była oświeceniowa "philosophia recentiorum”, „Kwartalnik Filozoficzny”, t. 26, 1998 , z. 1, s. 115-128. Por. idem, Oświecenie chrześcijańskie. Z dziejów polskiej kultury filozoficznej, Redakcja Wydawnictw Katolickiego Uniwersytetu Lubelskiego, Lublin 1994; F. Bargieł, Stanisław Szadurski SJ (1726-1789). Przedstawiciel uwspółcześnionej filozofii scholastycznej, Wydział Filozoficzny Towarzystwa Jezusowego w Krakowie, Kraków 1978; R. Darowski, Studia z filozofii jezuitów w Polsce XVII i XVIII wieku, Akademia Ignatianum - Wydawnictwo WAM, Kraków 1998.

18 Zob. S. Janeczek, Ideały wychowawcze w edukacji oświeceniowej (w perspektywie historii intelektualnej). Z dziejów Komisji Edukacji Narodowej, „Roczniki Kulturoznawcze”, t. 6, 2015, nr 2, s. 5-37. 
Newtona mającego ambicję zastąpienia w sposób systemowy filozofii przyrody Arystotelesa ${ }^{19}$.

Jak jednak skomplikowane okazało się wprowadzenie nowego systemu szkolnego, pokazują choćby perypetie z publikacją podręczników, gdyż do końca swego funkcjonowania, a więc przez ponad 20 lat, KEN nie dorobiła się ich kompletu do szkół średnich. Ukazała się tylko część podręczników do fizyki oraz botaniki i zoologii ${ }^{20}$. Nic dziwnego, że śladem szkoły tradycyjnej, ugruntowanej - jak wskazano wyżej - na kulturze autorytetu, Komisja musiała wykorzystać nawet w odniesieniu do najbardziej nowatorskiej warstwy kształcenia, jaką stanowiło przyrodoznawstwo, tzw. wypisy z autorów klasycznych. Służyły one nie tylko kształtowaniu właściwej kultury języka czy historii nauk, sztuk i rzemiosł, mineralogii czy nauki o zachowaniu zdrowia, ale też - paradoksalnie - nauczaniu przyrodoznawstwa ${ }^{21}$, a także historii nauk, sztuk i rzemiosł, mineralogii oraz nauki o zachowaniu zdrowia i prawa. W trzech pierwszych tomach Wypisów obecne są elementy historii naturalnej zaczerpnięte z pism Lucjusza Columelli, jednak poprawiane i uzupełniane rzetelnie $\mathrm{w}$ przypisach, odpowiednio do nowożytnej wiedzy o przyrodzie, aktualizowane do świata polskiej fauny i flory, a także kształtujące aktywną postawę gospodarczą i nowoczesne formy gospodarowania (kształcenie i wychowywanie) ${ }^{22}$.

Nic dziwnego, że w nowatorsko pomyślanej dydaktyce przyrodoznawstwa przeciwstawianego filozofii można dostrzec w dokumentach KEN refleks filozoficznego ujęcia przyrody, choć przestrzegała ona przed „próżnymi i nieco zapomnianymi spekulacjami”, traktowanymi jako „próżna około rzeczy fizycznych metafizyka”, a koncentrującymi się na uwikłanych historycznie dyskusjach czy wręcz kłótniach („,dysputy, opugny"). Miały się one odwoływać do minionych autorytetów oraz zamiast opisu przyrody koncentrowały się na poszukiwaniu „dalekich przyczyn", co w istocie sprowadzało się do nieużytecznych życiowo „domysłów bałamutnych, ciekawości płochych”. W miejsce „próżnej

19 Zob. S. Janeczek, Oświeceniowa kultura naukowa w kontekście filozoficznym. Z dziejów Komisji Edukacji Narodowej (Cz. 1-2), „Roczniki Filozoficzne”, t. 63, 2015, nr 4, s. 35-114; idem, Z badań nad przyrodoznawstwem w szkołach Komisji Edukacji Narodowej, w: Wierność rzeczywistości. Księga Pamiątkowa z okazji jubileuszu 50-lecia pracy naukowej na KUL O. prof. Mieczysława A. Krapca, Polskie Towarzystwo Tomasza z Akwinu, Lublin 2001, s. 699-712; idem, Epistemologia w dydaktyce fizyki Komisji Edukacji Narodowej, „Roczniki Filozoficzne”, t. 50, 2002, nr 1, s. 203-262; idem, Witalistyczno-mechanistyczna koncepcja życia w podręcznikach Komisji Edukacji Narodowej, w: Z potrzeby serca, red. Z. Krzyszowski i in., Instytut Wyższej Kultury Religijnej, Lublin 2004, s. 98-116.

20 Zob. C. Majorek, Ksiązki szkolne Komisji Edukacji Narodowej, Wydawnictwa Szkolne i Pedagogiczne, Warszawa 1975, s. 102-145.

${ }^{21}$ Wypisy z autorów klasycznych do nauk w szkotach narodowych stosowane na kl. I-III, Warszawa 1777-1780.

22 Por. C. Majorek, Ksiązki szkolne, s. 159-163. 
około fizycznych rzeczy metafizyki" postuluje KEN skoncentrowanie się na nowej nauce, zalecanej ze względu na jej cele i metody. W pierwszym przypadku dotyczy to użyteczności nowej wiedzy w praktyce życiowej, „rzetelnych korzyści”, jakie płyną z nauczanych treści, czyli wiązania teorii z praktyką ${ }^{23}$. Wyakcentowanie znaczenia przyrodoznawstwa dla użytecznych życiowo technologii nie musiało jednak oznaczać całkowitego zerwania nowoczesnej fizyki z tradycją filozoficzna, skoro synonimem przyrodników odkrywających $\mathrm{w}$ przyrodzie użyteczne nam rzeczy są dalej filozofowie ${ }^{24}$. Tak pojęte przyrodoznawstwo przestało być częścią kursu filozofii, jak $\mathrm{w}$ ujęciach recentiores $\mathrm{w}$ połowie wieku XVIII ${ }^{25}$. Faktycznemu podtrzymaniu więzi z tradycyjnymi koncepcjami filozofii przyrody służyła zapewne "krótka i historyczna wiadomość" o danych "systematach", unikająca jednak uciążliwych dyskusji między szkołami. Echem tych uwag są sformułowania Obwieszczenia od Komisji Edukacji Narodowej względem napisania ksiażek elementarnych do szkót wojewódzkich, które nakazywało podjęcie w podręczniku fizyki typowej

${ }^{23}$ Cel i status metodologiczny przedmiotów przyrodniczych przedstawiają następujące dokumenty KEN: Przepis Komisji Edukacji Narodowej, cyt za: Ustawodawstwo szkolne za czasów Komisji Edukacji Narodowej. Rozporzadzenia, ustawy pedagogiczne i organizacyjne (1773-1793), wyd. J. Lewicki, M. Arct, Kraków 1925, s. 36-39, 43; Obwieszczenie od Komisji Edukacji Narodowej względem napisania ksiażek elementarnych do szkót wojewódzkich, cyt za: Ustawodawstwo szkolne, s. 86-88; Ustawy Komisji Edukacji Narodowej, cyt. za: Komisja Edukacji Narodowej (pisma Komisji i o Komisji). Wybór źródeł, wyd. S. Tync, Zakład Narodowy im. Ossolińskich, Wrocław 1954, s. 671-673. Np. w odniesieniu do chemii Przepis stwierdza: „Chcąc chimją uczynić dobra, pożyteczna, odrzucić trzeba w jej traktowaniu domysły bałamutne, ciekawości płoche, często zatrudniające nazwiska, odrzucić systemata, trzymać się obserwacji, zaczynając od ziemi, od rzeczy gospodarskich, zawsze stosując nauki do potrzeb, do wygód ludzkich". Zob. Przepis Komisji Edukacji Narodowej, cyt za: Ustawodawstwo szkolne za czasów Komisji Edukacji Narodowej, s. 37.

24 Nie inaczej określał dziedzinę swojej twórczości twórca mechaniki klasycznej I. Newton, który nazywał ją zamiennie: „filozofia naturalna”, „filozofia eksperymentalna" lub "filozofia mechanistyczna”, ze względu na jej warstwę wyjaśniającą w zakresie dociekania sił występujących w przyrodzie. Zob. M. Heller, J. Życiński, Wszechświat - maszyna czy myśl?, Polskie Towarzystwo Teologiczne, Kraków 1988, s. 75-77. Por. M. Heller, Filozofia świata, Wydawnictwo "Znak”, Kraków 1992, s. $62-$ 79; Z. Hajduk, Filozofia przyrody Isaaca Newtona, "Studia Philosophiae Christianae”, t. 24, 1988, nr 2, s. 115-129; idem, Racjonalna rekonstrukcja filozofii przyrody Isaaca Newtona, w: Oblicza filozofii XVII wieku, red. S. Janeczek, Wydawnictwo KUL, Lublin 2008, s. $423-440$.

25 Zob. S. Janeczek, Przyrodoznawstwo w polskim szkolnictwie kościelnym okresu oświecenia, „Roczniki Filozoficzne”, t. 41, 1993, nr 3, s. 87-109; Z. Śmierzchalski, Fizyka doświadczalna jako dziedzina filozofii w okresie oświecenia w Polsce na przykładzie dzieł Józefa Rogalińskiego (1728-1802), Wydział Filozoficzny Towarzystwa Jezusowego, Kraków 1998; J. Skarbek, Pojęcia wstępne fizyki Antoniego Wiśniewskiego, „Studia i Materiały z Dziejów Nauki Polskiej", 1959, ser. A, nr 3, s. 181-203; F. Bargieł, Stanisław Szadurski SJ (1726-1789), s. 235-293. 
problematyki filozoficznoprzyrodniczej. Miała ona dotyczyć zarówno własności rzeczy materialnych, jak też materialnego substratu w formie doktryny "czterech elementów" (typowych dla arystotelesowskiej kosmologii), choćby i z zaznaczeniem, że należy to czynić „z wyłożeniem, ile się do pożytku codziennego ściągają". Istotną rolę w podtrzymaniu więzi nowożytnego przyrodoznawstwa z filozofią mógł odegrać wieńczący nauczanie w szkole średniej wykład historii nauk, umiejętności i sztuk, skoro przez wieki stanowiły one element filozofii pojętej jako wszechnauka.

W zakresie najwyżej metodologicznie cenionej fizyki KEN opublikowała podręczniki Michała Hubego w formie Wstępu do fizyki do szkót narodowych ${ }^{26}$, stanowiącego ogólne wprowadzenie w problematykę fizyczna, oraz Fizyki dla szkół narodowych, jako fizyki właściwej, w ramach której wydano tylko część pierwszą obejmującą Mechanikęę, jej rozwinięciem zaś miała być - niestety nie wydana - fizyka szczegółowa, jako „fizyka właściwa”, odpowiadająca w gruncie rzeczy treści obszernego Wstępu do fizyki do szkót narodowych. Obwieszczenie dotyczące publikacji podręczników traktowało tę problematykę integralnie, zalecając opracowanie jej jednemu autorowi. W dużej mierze nie inaczej stanowiły pijarskie Ustawy szkolne z połowy wieku XVIII, które poprzedzały wykład fizyki „zasadami matematyczno-fizycznymi”, a następnie wyróżniały problematykę poświęconą ogólnym właściwościom ciał i ich rodzajom w fizyce szczegółowej, m.in. ożywionym i nieożywionym ${ }^{28}$.

To eklektyczne podejście zdradza stopniowe przechodzenie od fizyki filozoficznej do stricte „naukowej”. Jeszcze jednak pod koniec działalności Komisji wspomniany Plan instrukcji zaleca w ramach fizyki ogólnej nauczanie o „własnościach pospolitych ciał, jako to: nieprzenikliwość, podzielność ciężkość, spójność", a nawet „opisanie czterech żywiołów, ich własności i działań w naturze, jako to światła, głosu, płynności, z tłumaczeniem własności temu akustycznych, optycznych, hydrostatycznych" itd., co zawierały wszystkie podręczniki europejskiej fizyki drugiej połowy wieku XVIII ${ }^{29}$. Ówczesne, już w dużej mierze eksperymentalno-matematyczne przyrodoznawstwo, mimo postępującego fenomenalizmu, operowało bowiem dalej substancjalistyczną wizją ciała materialnego (corpus naturale), które ma właściwości typowe dla wszystkich ciał i specyficzne dla poszczególnych ich rodzajów. Postawę tę ilustruje wspomniany asystemowy katalog cech ciał, który wzbogacano np. zjawiskami elektryczności i magnetyzmu, intrygującymi opinię

26 Kraków 1783.

27 Kraków 1792.

28 S. Konarski, Ustawy szkolne, przekł. W. Germain, M. Arct, Kraków 1925, s. 127, 132-134.

29 Cyt. za: Ustawodawstwo szkolne, s. 342-343. 
uczonych jeszcze w pierwszych dziesięcioleciach wieku XIX, pozwalając np. Fryderykowi W.J. Schellingowi odnowić filozofię przyrody na gruncie rozparcelowanego już na poszczególne dyscypliny przyrodoznawstwa $^{30}$. Takie podejście umożliwiało $\mathrm{w}$ ramach philosophia recentiorum podtrzymywanie filozofii przyrody traktującej o konstytucji ciała $\mathrm{w}$ formie złożenia z materii i formy, do czego dołączano równie filozoficznie ujęty atomizm, bo empirycznie ugruntowana atomistyka jest uprawiana dopiero od wieku XIX ${ }^{31}$. Fizyka oświeceniowa podtrzymywała także starożytna, filozoficzną przecież, wizję substratu rzeczywistości w formie tzw. elementów ${ }^{32}$, uzupełnianych o nowożytne pierwiastki ${ }^{33}$.

Jak niedaleko od praktyki recentiores odszedł podręcznik Hubego, ilustruje zestawienie go z Fizyka doświadczeniami potwierdzona, promotora górnictwa i hutnictwa, pijara Józefa H. Osińskiego, zwanego pierwszym polskim elektrykiem ${ }^{34}$. Różnice ujawniają się nie tyle na poziomie treści, ile raczej metodyki, a właściwie tylko struktury wykładu. Przy zachowaniu bowiem niemal wszystkich rozdziałów z fizyki pijara Hube odwraca tylko ich kolejność, do czego zmusiła go KEN, co innego bowiem proponował Komisji w projekcie podręcznika ${ }^{35}$. O ile bowiem Hube w zgodzie ze standardami indukcjonizmu kończy przedstawienie podstawowych typów ciał omówieniem ogólnej specyfiki określanej wcześniej jako corpus naturale, po którym następuje omówienie zasad mechaniki,

30 Zob. L. Miodoński, Całość jako paradygmat rozumienia świata w myśli niemieckiej przełomu romantycznego, Oficyna Wydawnicza Arboretum, Wrocław 2001.

31 Zob. A. C. Crombie, Nauka średniowieczna i poczatki nauki nowożytnej, t. 2, przekł. S. Łypacewicz, Instytut Wydawniczy „Pax”, Warszawa 1960, s. 153-207, 348-406; H. Butterfield, Rodowód wspótczesnej nauki 1300-1800, przekł. H. Krahelska, PWN, Warszawa 1968, s. 114-134, 185-202.

32 Do koncepcji starożytnych żywiołów odwoływał się także d'Alembert, zob. J. Le Rond d'Alembert, Wstęp do „Encyklopedii”, przekł. J. Hartwig, PWN, Warszawa 1954, s. 143.

33 Właściwa chemia rozwinęła się dopiero w ostatnim ćwierćwieczu wieku XVIII, a jej podstawowym osiągnięciem było właściwe ujęcie natury spalania, które zakłada aktywność chemiczną tlenu, co w istocie należy dopiero uznać za początek rewolucji chemicznej zapoczątkowanej przez Antoine Lavoisiera. Koncepcja ta pozwoliła przezwyciężyć prostacki mechanicyzm związany ze swoistym fizykalizmem najbardziej zawansowanej (empirycznej i matematycznej) części przyrodoznawstwa. Zob. A. C. Crombie, Nauka średniowieczna i początki nauki nowożytnej, t. 2, s. 318-319; H. Butterfield, Rodowód współczesnej nauki 1300-1800, s. 388-389.

34 Warszawa 1777. Zob. Z. J. Wójcik, Udział OO. pijarów w rozwoju przyrodoznawstwa w Polsce doby Oświecenia, w: Wkład pijarów do nauki i kultury w Polsce XVII-XIX wieku, red. I. Stasiewicz-Jasiukowa, Zakład Historii Nauk Społecznych IHNOiT PAN, Warszawa 1993, s. 219-237; J. Buba, Józef Herman Osiński. Pierwszy elektryk polski, hutnik i chemik, w: idem, Pijarzy w kulturze dawnej Polski, Polska Prowincja XX Pijarów, Kraków 1982, s. 236-242.

35 Sur le plan de physique, cyt. za: J. Lubieniecka, Towarzystwo do Ksiag Elementarnych, Nasza Księgarnia, Warszawa 1960, s. 183. 
to recentiores podtrzymują konsekwentnie quasi-dedukcyjną konwencję, rozpoczynając wykład od problematyki najogólniejszej. Pijar Osiński obejmując całokształt zagadnień fizycznych, łącznie z mechaniką i ich technicznymi zastosowaniami (np. kolejno natura wody, hydrostatyka i hydraulika, przedstawiona w kontekście „machin społeczności użyteczniejszych"), a więc zespalając tematykę obu prac Hubego - najpierw przedstawia problematykę "ciała i jego własności w powszechności", by przejść do mechaniki, począwszy od siły przyciągania („attrakcya”), a następnie różnych rodzajów ciał i właściwych im zjawisk z zastosowaniami technicznymi, kończąc na astronomii wieńczącej też Mechanikę Hubego. Co ciekawsze, o ile ujęcia Osińskiego i Hubego charakteryzuje w równym stopniu dążenie do geometrycznego wyrażenia zjawisk przyrodniczych, o tyle niewątpliwie podręcznik pijara, przy zachowaniu opcji mechanistyczno-korpuskularnej, charakterystycznej także dla podręcznika fizyki KEN, jest bardziej fenomenalistyczny. Podręcznik Osińskiego mniej uwagi zwraca bowiem na naturę zjawisk, np. światła czy ognia, a bardziej na specyfikę ich poszczególnych przejawów, a więc paradoksalnie jest bardziej „naukowy” (w sensie empirystycznym) niż teoretyzujące, a więc - uwzględniając ówczesne realia - bardziej filozoficzne ujęcie Hubego.

Zbieżność tych ujęć nie jest przypadkowa, gdyż przed opublikowaniem podręcznika Hubego zalecała KEN opracowania recentiores, które ceniła również Wielka encyklopedia francuska, eklektyczna jak cała kultura oświeceniowa, pod której wpływem pozostawała niewątpliwie Komi$\mathrm{sja}^{36}$. Otwarty kulturowo eklektyzm umożliwiał bowiem wykorzystanie zróżnicowanych tradycji filozoficznych i naukowych ${ }^{37}$. W odniesieniu do nauczania fizyki KEN zalecała dzieła Pietera van Musschenbroeka ${ }^{38}$,

36 Zob. S. Janeczek, Komisja Edukacji Narodowej a "Encyklopedia, albo słownik rozumowany nauk, sztuk i rzemiost”, cz. 2: Wymiar dydaktyczny, "Zeszyty Naukowe KUL” 59(2016), nr 2(234), s. 3-22.

37 D. Diderot, redaktor Encyklopedii stwierdza: „powinno się wymagać ode mnie, żebym szukał prawdy, a nie, żebym ją znalazł", co jest synonimem postawy „badającej, ale nie rozstrzygającej”, uznając tę drugą za wyraz „głupiej zarozumiałości dogmatycznej". D. Diderot, Myśli filozoficzne, w: Wybór pism filozoficznych, przekł. J. Hartwig, J. Rogoziński, Państwowy Instytut Wydawniczy, Warszawa 1960, s. 35, 38. Antysystemowy i antydogmatyczny charakter eklektyzmu ujawniał się w modnych ówcześnie ujęciach z zakresu historii filozofii, np. Johanna J. Bruckera. Nie przypadkowo więc Johann F. Buddeus, nauczyciel Bruckera, przeciwstawiając się systemowi Christiana Wolffa wołał, jak liczni eklektycy niemieccy: „Precz z systemami”. Cyt. za: M. Skrzypek, Filozofia Diderota, Wydawnictwo IFiS PAN, Warszawa 1996, s. 142-144.

38 P. van Musschenbroek, Institutiones physicae, Lugduni Batavorum 1748; Introductio ad philosophiam naturalem, t. 1-2, Lugduni 1762; idem, Physicae experimentalis, et geometricae, magnitudinae terrae, cohaerentia corporum firmorum disserationes; ut et ephemerides meteorologicae ultraiectinae, Lugduni Batavorom 1729; idem, Dissertatio experimentalis de magnete, Vienna 1754. Ze Wstępu do filozofii naturalnej Musschenbroeka 
profesora fizyki na uniwersytetach niemieckich i holenderskich, członka Royal Society, autora wielu podręcznikowych opracowań wydawanych w różnych krajach Europy z zakresu fizyki eksperymentalnej, zwłaszcza dotyczących zjawiska magnetyzmu, i jezuity Jean-Antoine Nolleta ${ }^{39}$, pierwszego profesora fizyki eksperymentalnej na Uniwersytecie w Paryżu, członka Akademii Francuskiej ${ }^{40}$. W kwestii nauczania mineralogii zespolonej z chemią Przepis zalecał dzieła królewskiego lekarza, tłumacza i autora z zakresu fizyki i chemii Petera Schawa ${ }^{41}$ i paryskiego lekarza Pierre-Josepha Macquera ${ }^{42}$. Nie inaczej w odniesieniu do historii naturalnej, gdzie Przepis zalecał reprezentatywne ujęcia w perspektywie współczesnych standardów historii nauki, tj. prace wspomnianego wyżej Buffona ${ }^{43}$, ale także popularnych podówczas minores, jak Noël-Antoine de Pluche ${ }^{44}$, którego Encyklopedia zalecała w zakresie kosmologiii ${ }^{45}$,

korzystał także profesor fizyki Akademii Wileńskiej J. Mickiewicz, Układ lekcji w Akademii Wileńskiej na r. 1782, Wilno 1781. Zob. I. Szybiak, Szkolnictwo Komisji Edukacji Narodowej w Wielkim Księstwie Litewskim, Zakład Narodowy im. Ossolińskich, Wrocław 1973 , s. 56-57.

39 J. A. Nollet, Leçons de physique expérimentale, t. 1-6, Paris 1764 (tom pierwszy ukazał się w roku 1743, a kolejne do 1764 r., przy czym tom pierwszy już po raz szósty). Wg ujęcia Nolleta pierwszy wydany po polsku podręcznik do empirycznej fizyki opracował pijar Samuel Chróścikowski Fizyka doświadczeniami potwierdzona, Warszawa 1764.

40 Jean-Baptiste de La Chapelle, sygnowany jako „E”, francuski ksiądz i matematyk, członek Royal Society, uzupełniając hasło napisane przez d'Alemberta, informował o ujęciach z zakresu matematyki i fizyki w odniesieniu do problematyki poruszanej w haśle Élémens des sciences (Philosophie): „Les meilleurs élémens de Physique sont l'essai de Physique de Musschenbroeck, les élémens de s'Gravesande, les leçons de Physique de M. l'abbé Nollet, \& plusieurs autres", Encyclopédie ou dictionnaire universel raisonné des sciences, des arts et des métiers, t. 5, s. 497.

41 P. Schaw, Leçons de Chymie. Propres à perfectionner la physique, le commerce et les arts, przekł. M.-G.-Ch. Thiroux d'Arconville, Paris 1759. Jest to przekład Chemical lectures publicly read at London, in the years 1731, and 1732, and at Scarborough, in 1733, for the improvement of arts, trades, and natural philosophy, London $1755^{2}$.

42 Zalecane przez Przepis "Leçons de Chymie Théorique et Pratique" to zapewne Élémens de chymie-théorique (Paris 1749) i Élémens de chymie-pratique, contenant la description des opérations fondamentales de la chymie, avec des explications $\mathcal{E}$ des remarques sur chaque opération (t. 1-2, Paris 1751; idem jako Elements of the Theory and Practice of chymistry, przekł. A. Reid, Edinburgh 1768). Macquer był najbardziej znany jako autor piewszej encyklopedii chemii, tłumaczonej na wiele języków Dictionnaire portatif des arts et métiers (contenant en abrégé l'histoire, la description et la police des arts et métiers, des fabriques et manufactures de France et des pays etrangers, t. 1-2, Paris 1766.

43 G. L. Buffon, Historie naturelle, t. 1-44, Paris 1749-1804.

44 Zob. przyp. 15.

45 Histoire du ciel où l'on recherche l'origine de l'dolâtrie et les méprises de la philosophie sur la formation et sur les influences des corps célestes, t. 1-2, Paris 1711-1740². Ceni Pluche anonimowy autor hasła Philosophie, krytykując obsesję ducha systemów: „L'esprit systématique ne nuit pas moins au progrès de la vérité : par esprit systématique, je n'entends pas celui qui lie les vérités entre elles, pour former des démonstrations, ce 
czy Jacques-Christophe Valmont de Bomare ${ }^{46}$. Nie można jednak nie zauważyć, że bogatszy zestaw lektur prezentujących współczesną sobie literaturę przedmiotu zalecały już pijarskie Ustawy szkolne ${ }^{47}$.

Jak wskazano wyżej, Philosophia recentiorum, asymilując eklektycznie dokonania nowożytnego przyrodoznawstwa, nie tylko dziedziczyła elementy podejścia filozoficznego w ujmowaniu specyfiki przyrody, choćby równie widoczna była tendencja przechodzenia od substancjalistycznie ujętego przyrodoznawstwa w kierunku ujęć konsekwentnie fenomenalistycznych; dzieliła także religijną perspektywę wciąż właściwą oświeceniowej Europie ${ }^{48}$. Splot tych dwóch tendencji ujawnił się na gruncie biologii, która stanowiła, obok mineralogii, element historia naturalis, systemowo ugruntowanej $\mathrm{w}$ arystotelesowskiej interpretacji o charakterze witalistycznym, organicystycznym ${ }^{49}$. Dopiero za sprawą Kartezjusza pojawiła się nowa koncepcja funkcjonowania organizmów żywych $\mathrm{w}$ formie fizyko-chemicznego mechanicyzmu. Wiązał on redukcjonistycznie aktywność duszy ludzi i zwierząt z funkcjami ciała, traktowanego jako maszyna kierowana przez duszę za pomocą mózgu, w którym znajduje się jej „siedziba” ${ }^{50}$.

qui n'est autre chose que le véritable esprit philosophique, mais je désigne celui qui bâtit des plans, \& forme des systèmes de l'univers, auxquels il veut ensuite ajuster, de gré ou de force, les phénomènes ; on trouvera quantité de bonnes réflexions là-dessus dans le second tome de l'histoire du ciel, par M. l'abbé Pluche. Il les a pourtant un peu trop poussées, \& il lui seroit difficile de repondre à certains critiques". W: Encyclopédie ou dictionnaire universel raisonné des sciences, des arts et des métiers, t. 12, s. 515.

46 J.-Ch. Valmont de Bomare to nauczyciel różnych działów historii naturalnej oraz pracownik ówczesnych gabinetów przyrodniczych, KEN zalecała jego Dykcjonarzyk, czyli publikowany wielokrotnie aż po rok 1800 Dictionnaire raisonné d'histoire naturelle, Paris 1764.

47 S. Konarski, Ustawy szkolne, s. 132-136.

48 Jak słusznie zwraca uwagę Jeremy Blake, w oświeceniowych, na pozór radykalnie nowatorskich przemianach, należy dostrzegać ich ciągłość, nawet jeśli „niektórzy autorzy ... określali swe idee przez opozycję do dokonań przeszłości", to jednak „większość podążała inną drogą i nawet ci, którzy akcentowali zmianę, często sięgali po idee zaczerpnięte z przeszłości". J. Blacke, Europa XVIII wieku 1700-1789, przekł. M. Domańska, Państwowy Instytut Wydawniczy, Warszawa 1997, s. 275. Dotyczy to w szczególności miejsca, jakie zajmowała w nich religia, stąd też protestuje przeciwko opinii o desakralizacji kultury oświecenia, gdyż „po pierwsze, należy odróżniać zmiany wrażliwości religijnej od objawów jej zaniku, po drugie, świadectwa, jakimi dysponujemy, wskazują że sceptycyzm, choć niewątpliwie obecny, to zjawisko marginesowe i że o wiele powszechniejszym fenomenem była bogata religijność ludowa, często niepodatna na wpływy reformatorsko nastawionych duchownych". Ibidem, s. 234.

49 Zob. S. Swieżawski, Albertyńsko-tomistyczna a kartezjańska koncepcja człowieka, „Przegląd Filozoficzny”, 1947, t. 43, z. 1-4, s. 87-114. Por. Essays on Aristotle`s „De anima", red. M. C. Nussbaum, O. Rorty, Clarendon Press, Oxford 1992.

50 A. C. Crombie, Nauka średniowieczna, t. 2, s. 299. Por. ibidem, s. 292-300, 321-348. Zob. A. R. Hall, Rewolucja naukowa 1500-1800. Kształtowanie się nowożytnej po- 
Autorem dwóch z trzech zaplanowanych podręczników do historii naturalnej został ostatecznie proboszcz ciechanowski Krzysztof Kluk, przygotowując tomy dotyczące botaniki i zoologii ${ }^{51}$. Kluk podtrzymał w historii naturalnej wizję trzech królestw świata przyrody, ale akcentował jednocześnie zarówno rozróżnienie na ciała organiczne i nieorganiczne (corpora inorganisata i organisata), jak też na organizmy posiadające duszę lub też nie, a więc "ciała organiczne żyjące" (corpora organisata animata) na oznaczenie zwierząt i "ciała organiczne bezduszne" (corpora organisata inanimata) w odniesieniu do roślin ${ }^{52}$. Postawą tych wyróżnień jest więc kategoria "organizacji” i „ożywienia” niejasno łączonego, lub też nie, z duszą. W przypadku roślin źródłem zdolności czy też funkcji przyswajania pokarmów, wzrostu i ciągłości gatunkowej byłaby natomiast ich specyficzna "organizacja”, nie zaś dusza, charakterystyczna dla świata zwierząt i człowieka. Zwierzęta wyróżniają od roślin funkcje sensytywne i lokomocyjne, $\mathrm{z}$ „wewnętrznej pochodzące mocy"53, traktowanej jako „dusza, ale niższego stopnia" ${ }^{54}$, która umożliwia im nawet uczenie się $e^{55}$. Choć Kluk także człowieka traktował aspektywnie jako zwierzę, to nie omieszkał zaznaczyć, że ma on duszę różną od zwierzęcej, wyższa, rozumna, co przesądza o doskonałości człowieka ${ }^{56}$.

Proces odchodzenia od trójpoziomowej koncepcji duszy (wegetatywnej, sensytywnej i racjonalnej) zaznaczył się jednak już u polskich recentiores, którzy zrezygnowali z kategorii duszy wegetatywnej, jak np. pierwszy nowoczesny fizyk polski, jakim był pijar Antoni Wiśniewski,

stawy naukowej, przekł. T. Zembrzuski, Instytut Wydawniczy „Pax”, Warszawa 1966, s. 323-353; H. Butterfield, Rodowód współczesnej nauki, s. 203-225. Por. H. Kirkinen, Les Origines de la conception moderne de l'homme-machine. Le problème de l'âme en France 1670-1715, Suomalainen Tiedeakatemia, Helsinki 1969. Nie można jednak zapomnieć, że sam Kartezjusz jedność tych dwu elementów ujmował raczej w perspektywie epistemologicznej (praktycznej) niż metafizycznej, doznania duszy (uczucia) nie są bowiem efektem jej własnej aktywności, ale są spowodowane przez „zewnętrzne" wobec niej ciało, choć postrzegane jako „moje”, , własne”. J. Kopania, Szkice kartezjańskie, Aureus, Kraków 2009, s. 109, 116; por. ibidem, s. 100-124.

51 K. Kluk, Botanika dla szkót narodowych, Warszawa 1785; K. Kluk, P. Czempiński, Zoologia czyli zwierzętopismo dla szkół narodowych, Warszawa 1789.

52 K. Kluk, Botanika, s. 1-2.

53 Ibidem, s. 2; K. Kluk, P. Czempiński, Zoologia, s. 1.

54 K. Kluk, P. Czempiński, Zoologia, s. 44-45. Bardziej wymownym okaże się Kluk w obszernej czterotomowej zoologii, kiedy to jednak także eklektycznie, choć - jego zdaniem - w zgodzie z przeważającą opinią filozofów uzna, że dusza zwierzęca jest „duchem pośrednim między ciałem i duszą człowieka”, czyli ani jest materialna, ani też duchem człowieka". K. Kluk, Zwierząt domowych i dzikich, osobliwie krajowych, historii naturalnej początki i gospodarstwo, t. 1, Warszawa 1779, s. 110-113.

55 K. Kluk, P. Czempiński, Zoologia, s. 44-45.

56 Ibidem, s. 2, 45. 
który omawiał tylko duszę zwierzęcą ${ }^{57}$. Ironizowano nawet $\mathrm{z}$ „duszki" (animula) roślinnej, odrzucanej przez nowożytnych ${ }^{58}$. Rozstrzygnięcia te napotykały jednak trudność $\mathrm{w}$ wytłumaczeniu analogii $\mathrm{w}$ zakresie czynności życiowych roślin i zwierząt, którą dzielił tak prominentny przyrodnik doby oświecenia, jakim był Buffon. O ile wyraźnie przeciwstawiał on świat ożywiony minerałom, to zacierał różnicę między zwierzętami i roślinami, które były $\mathrm{w}$ równym stopniu zbudowane $\mathrm{z}$ drobin organicznych ${ }^{59}$.

Nie inne podejście można znaleźć w podręczniku przyrodoznawstwa używanym w szkołach monarchii habsburskiej, który prezentował natürliche Dinge, wychodząc od omówienia filozoficznie ukierunkowanej Naturlehre, czyli od przedstawienia pierwszorzędnych (allgemeine Eigenschaften) i szczególnych (besondere Eigenschaften) właściwości ciał, a następnie ich podstawowych rodzajów. Obok ognia, powietrza, wody, podręcznik przedstawiał bowiem naturę światła, elektryczności i magnetyzmu, a następnie strukturę makrokosmosu w duchu systemu Kopernika ${ }^{60}$, wraz ze zjawiskami atmosferycznymi ${ }^{61}$. Korpus tego podręcznika stanowi historia naturalna (Naturgeschichte) - od zoologii przez botanikę do mineralogii ${ }^{62}$. Odpowiednio do filozoficznego ujęcia rzeczywistości, tzw. Naturalia ujmowane są zasadniczo jako ciała, a nie substancje $^{63}$. Jednak i ta wizja przyrody jest dalej nie tylko uwikłana filozoficznie, ale także odpowiada światopoglądowi chrześcijańskiemu, skoro przez „świat” rozumie się „wszystkie przez Boga stworzone rzeczy", i to nie tylko ciała, ale także duchy (Geister, Geisterwelt), choćby

57 A. Wiśniewski, Propositiones philosophicae, ex illustribus veterum recentiorumque philosophorum placitis depromptae, Varsaviae 1752, tezy LXVII-LXX.

58 F. Bargieł, Stanistaw Szadurski SJ, s. 278.

59 G. L. Buffon, Histoire naturelle, t. 2, Paris 1749, s. 9-10. Cyt. za: A. Bednarczyk, Filozofia biologii europejskiego Oświecenia, PWN, Warszawa 1984, s. 166-167. Por. J. Roger, Les sciences de la vie dans la pensée française du XVIIIe siècle, Michel, Paris 19933, s. 547-551. Pewnie więc ze względu na ten eklektyzm biologii oświeceniowej, nieporównanie bogatszej na poziomie dokumentacyjnym niż interpretacyjnym w zakresie rozumienia procesów życiowych, Karol Darwin, przeczytawszy w 1882 r. przekład traktatu Arystotelesa O częściach zwierząt, pisał: „Na podstawie cytatów, które widziałem, miałem wysokie wyobrażenie o zasługach Arystotelesa, ale nie miałem najmniejszego wyobrażenia, jak znakomitym był człowiekiem. Linneusz i Cuvier - to byli moi dwaj Bogowie, choć w bardzo różny sposób; ale w porównaniu ze starym Arystotelesem są oni zwykłymi uczniakami". The Life and Letters of Charles Darwin, t. 2, New York 1896, s. 427. Cyt. za i w tłumaczeniu A. Krokiewicza, Zarys filozofii greckiej, Aletheia, Warszawa 2000, s. 336.

${ }^{60}$ Kenntnisse von natürlichen Dingen zum Gebrauche der studierenden Jugend in den kaiserl. königl. Staaten, Wien 1781, s. 23.

61 Ibidem, s. 3-37.

62 Ibidem, s. 38-186.

63 Termin 'substancja' pojawia się tylko w sensie niefachowym na określenie pożywienia przyjmowanego przez ciała ożywione (fremde Substanzen). Ibidem, s. 39. 
z natury rzeczy tylko ten pierwszy świat był przedmiotem przyrodoznawstwa. Niemniej jednak podręcznik ten - w duchu zmodyfikowanej arystotelesowskiej psychologii filozoficznej - dostrzeże, że przynajmniej jeśli idzie o niektóre ciała ożywione (organisierte Körper), ich specyfikę określi związek duszy z ciałem, ale tylko w odniesieniu do zwierząt, bo już nie roślin, w pierwszym przypadku w formie zdolności doznawania, świadomości i ruchu kierowanego wolą ${ }^{64}$ Szukając zaś specyfiki człowieka w stosunku do zwierząt, a ściśle: najbliższych im Primates, wskaże, że należy jej poszukiwać nie tylko w naszym wyglądzie i specyfice ciał, ale także w zdolnościach duszy i języku, co tłumaczy przedstawienie natury duszy $\mathrm{w}$ duchu nowożytnego arystotelizmu chrześcijańskiego ${ }^{65}$, zwłaszcza w kategoriach jej duchowości i nieśmiertelności oraz wyposażenia we władze rozumu i woli ${ }^{66}$. Trzeba jednak podkreślić, że ten kontekst filozoficzny nie ujawnia się w dalszych rozważaniach, które mają charakter stricte przyrodniczy, koncentrując się na opisie zewnętrznego wyglądu omawianych stworzeń. Podręcznik jest bowiem nader wstrzemięźliwy co do analizy wewnętrznej struktury organizmów. Tylko w odniesieniu do świata roślin zaznacza, że nie jest ona łatwa do określenia, jak struktura zewnętrzna, dlatego ograniczy się do wskazania, że w ich budowie występują rozmaite dziurki czy rurkowate zbiorniki („verschiedene Höhlungen [...] röhrenförmige Gefässe), na całej ich długości, które umożliwiają wchłanianie wody, soku i powietrza, zapewniające odżywianie i wzrost ${ }^{67}$.

Nie można nie docenić, że ujęcie Kluka na poziomie mechanistycznej interpretacji życia jest nieporównanie bogatsze od podręcznika właściwego monarchii habsburskiej. Kluk usiłował bowiem zespolić w jednorodnej interpretacji mechanistycznej anatomię, morfologię i fizjologię, a zalążkowo także embriologię roślin i zwierząt ${ }^{68}$. Rośliny - podobnie zresztą jak zwierzęta - zbudowane są z części stałych (partes solidae)

64 Specyfikę zwierząt określa „eine Empfindung und ein Bewußtsenn nebst dem willführliche Bewegungen ihre Gliedmassen”, gdyż „alle diese Eigenschaften seßen eine mit dem Körper verbundene Seele”, stąd też zwierzęta to „organisierte, beseelte Körper, die eigentlich wachsten, leben und empfinden”, natomiast rośliny mogą ,eigentlich wachsten und leben", ale „weder empfinden, weder beseelet sind". Ibidem, s. 39 .

65 „Der Mensch unterscheidet sich von allen übrigen Thieren, nicht nur durch die Bildung und andere Vorzüge des Körpers, sondern auch und besonders durch die Seelenkräfte und Sprache". O, s. 45.

66 „Die Seele des Menschen ist ein einfaches, nicht zusammengesetztes, geistiges, unsterbliches, immer fortwährendes Wesen. Ihre Kräfte sind der Verstand und der Wille". Ibidem, s. 46.

67 Ibidem, s. 116.

68 Problematykę anatomii, morfologii i fizjologii z embriologią omawia K. Kluk w Botanice (s. 7-141), zwłaszcza w rozdz. I „O pierwiastkach składających zewnętrzne roślin części” (s. 8-27), po czym następuje systematyka roślin (s. 132-220). Czyni to 
i płynnych (partes fluidae), przy czym pierwsze dzieli na „pełne”, do których należą włókna (fibrae) i elementy „dęte”, czyli przede wszystkim rurki (tubuli). Strukturę roślin stanowi mechanicznie pojęty system posklejanych ze sobą włókien (fibra) zbudowanych z "cząstek ziemnych", tworzących powiązane i złączone klejem roślinnym (glutina vegetabilia) wiązki (fasciculi) oraz otoczonych wielowarstwową skórą (culicula, epidermis). Pomiędzy zaś tymi włóknami jest system „dętych naczyń", czyli pęcherzyków (utriculi) i walcowatych rurek zbudowanych ze skórek, które przewodzą wodę (tubuli aquaei), sok (tubuli succi nutritivi) lub powietrze (tracheae) ${ }^{69}$. Retorykę mechanicyzmu zastosował Kluk także do procesu odżywiania, oddychania i wzrostu (swoiste jedzenie i picie) $\mathrm{w}$ formie stopniowego przekształcania się pierwiastków pobieranych z otoczenia (solne, olejne, ziemne), które roślina stopniowo przekształca w związki organiczne, „w swoją istotę zamienia" tak, iż „coraz bardziej się doskonali i własności rośliny nabiera”, rozcieńczając je i „zaprawiając" własnym rozczynem (fermentum $)^{70}$. Także w Zoologii Kluk nie mógł wyjść w analizie procesów życiowych poza język mineralogii, omawiając bowiem system mięśniowo-kostny, wymieniał obok tradycyjnych żywiołów (woda, powietrze) nowożytne quasi-pierwiastki (oleje i sole), a także elementy typowe dla nowoczesnej chemii (wapno, żelazo) ${ }^{71}$. Nie znając jednak natury procesu spalania, źródło ciepłoty organizmu tłumaczył tarciem cząstek krwi zmuszonych do przesuwania się po coraz to węższych przewodach, co ma być źródłem wydzielania się „żywiołu palnego", a więc cząstek ciepła, czyli flogistenu, jako źródła procesu spalania, które przenikają do/i z krwi w procesie oddychania, zabarwiają ją na czerwono ${ }^{72}$. Koncepcja Kluka, grzesząca brakiem rozumienia elementarnych procesów chemicznych, zwłaszcza spalania, a tym bardziej roli białka, nie różni się jednak nawet od koncepcji Buffona, który unikał dyskusji na temat przekształcania się ciał nieorganicznych w organiczne, a jedynie zakładał obrót $\mathrm{w}$ przyrodzie substancji organicznych oraz

analogicznie także w Zoologii (s. 1-80), gdzie jednak nieproporcjonalnie rozbudowuje systematykę zwierząt (s. 81-397).

69 K. Kluk, Botanika, s. 8-19.

70 „Dlatego tak Bóg sporządził, że organiczne ciało pospolicie tylko przyjmuje zdatne sobie pożywienie, które dla wciskania się i osiadania, musi niejako robić (fermentare), tak drobnieje, istoty właściwej nabiera, i z soku wodnistego, sokiem się już pożywnym roślinie przyswojonym stanie. Sok więc pożywny roślin, jest cieczeń wodna, mająca w sobie rozpuszczone cząstki ziemne z cząstkami słonymi i olejnymi: od roślin zgniłych pochodzącymi, własnym rozczynem (fermentum) zaprawione). K. Kluk, Botanika, s. 22. Por. ibidem, s. 2-25.

${ }^{71}$ K. Kluk, P. Czempiński, Zoologia, s. 64.

72 Ibidem, s. 12, 19. 
traktował odżywianie jako wchłanianie przez organizm przejętych z zewnątrz drobin organicznych ${ }^{73}$.

Tak jak w przypadku podręcznika austriackiego podtrzymanie przez Kluka filozoficzno-religijnej koncepcji duszy nie wpłynęło na szczegółowe analizy świata przyrody. Typowa dla średniowiecza i renesansu perspektywa analiz biologicznych uwidoczniła się na zasadzie longue durée także $w$ dokonaniach najwybitniejszych przyrodników oświecenia. Była ona typowa np. dla najwybitniejszego systematyka ówczesnej biologii, jakim był Karol Linneusz, który zaliczał co prawda w aspekcie cech anatomicznych człowieka do naczelnych, ale zaznaczał, że wykracza on poza świat zwierząt, jest bowiem stworzony na podobieństwo Boże, z duszą nieśmiertelną, i obdarzony rozumem na chwałę Stwórcy; jest więc panem stworzenia zamykającym to dzieło, choćby naznaczonym przygodnością egzystencji ${ }^{74}$. Podobnie człowieka ujmował wspominany wyżej Buffon, który umieścił go na szczycie hierarchii życia ze względu na niematerialną rozumną duszę ${ }^{75}$. Stąd to człowiek w ujęciu Linneusza i Buffona jest dalej punktem odniesienia $\mathrm{w}$ rozumieniu uporządkowanego bogactwa świata przyrody, swoistej drabiny stworzeń. U podstaw tej filozoficzno-religijnej perspektywy tkwiło bowiem przekonanie o racjonalności natury ugruntowanej wizją wszechwiedzy i wszechmocy Boga-Stwórcy, niezależnie od tego, czy zakorzenionej w religii naturalnej, czy w kontekście wyznaniowym ${ }^{76}$. Dostrzeżony przez Kluka porządek przyrody stanowił okazję do podkreślania „zasług” jej Stwórcy, o którego wszechmocy, mą-

73 A. Bednarczyk, Filozofia biologii, s. 165-168; J. Roger, Les sciences de la vie, s. $547-51$.

74 C. Linnæus, Systema naturae per regna tria naturae secundum classes, ordines, gene$\mathrm{ra}$, species cum characteribus, differentiis, synonymis, locis, t. 1, Vindobonae $1767^{13}$.

75 G. L. Buffon, De l'homme, wyd. M. Duchet, Maspero, Paris 1971, s. 3-15. Nie można jednak nie wspomnieć o światopoglądowych perypetiach Buffona w odniesieniu do jego koncepcji genezy rozwoju przyrody, aż do powstania człowieka, w wydanej w 1749 r. Théorie de la Terre, potępionej w 1751 r. przez Sorbonę za wypowiedzi sprzeczne z literalną interpretacją Biblii, które po okresowym ich wyrzeczeniu się przedstawił ponownie w Discours des époques de la nature (1773-1774). E. Guyénot, Les sciences de la vie aux XVII et XVIII siècles. Liidée d’évolution, A. Michel, Paris 1957, s. 353-357. Należy jednak pamiętać, że jeszcze Wolter nie chciał dostrzec rozwoju przyrody, atakując osiągnięcia ówczesnej paleontologii. P. Chaunu, Cywilizacja wieku oświecenia, PIW, Warszawa 1993, s. 209-215. Oświeceniowa historia w dużej mierze pozostawała w służbie filozoficznej i światopoglądowo zorientowanej antropologii. Zob. S. Janeczek, Historyczna czy filozoficzna koncepcja religii Hugona Kołtataja?, w: Mithistoria - kultura, red. J. Skoczyński, Wydawnictwo Akademickie UJ, Kraków 2012, s. 23-32.

${ }^{76}$ Zob. S. Janeczek, Od filozofii Boga do filozofii religii w dobie oświecenia, w: Filozofia a religia. Inspiracje - krytyka, red. S. Janeczek, A. Starościc, Wydawnictwo KUL, Lublin 2014, s. 85-108. 
drości i dobroci „woła” wręcz sama natura ${ }^{77}$. I w tym więc przypadku nowożytna nauka funkcjonuje nie tylko w kontekście wątków filozoficznych, i to zaczerpniętych z nowożytnego arystotelizmu chrześcijańskiego, znakomicie oddając kierunki ówczesnych zmian, ale też ciągłości kultury filozoficznej, ugruntowanej nadto w religijnej kulturze oświecenia. Podejście to dzieli KEN za ówczesną szkołą europejską, właściwą także oświacie Rzeczpospolitej już od połowy wieku XVIII.

\section{Bibliografia:}

Alembert J. le Rond d', Discours préliminaire de l'Encyclopédie, w: CEuvres complètes de d'Alembert, red. A. Belin, t. 1, Paris 1821; reprint: Slatkine, Genève 1967; idem jako: Wstęp do „Encyklopedii”, przekł. J. Hartwig, PWN, Warszawa 1954.

Banaszkiewicz A., Karta Praw Podstawowych jako "uwieńczenie” unijnego systemu ochrony praw człowieka, „Studia Erasmiana Wratislaviensia”, t. 4, 2010, s. 175-193.

Bargieł F., Stanisław Szadurski SJ (1726-1789). Przedstawiciel uwspótcześnionej filozofii scholastycznej, Wydział Filozoficzny Towarzystwa Jezusowego w Krakowie, Kraków 1978.

Bednarczyk A., Filozofia biologii europejskiego Oświecenia, PWN, Warszawa 1984.

Blacke J., Europa XVIII wieku 1700-1789, przekł. M. Domańska, Państwowy Instytut Wydawniczy, Warszawa 1997.

77 K. Kluk, Zwierząt domowych, t. 1, s. 3-7, 134-135. Nie inaczej wołał Michał Hube, wieńcząc swój podręcznik: „O, jak wielki zatem Bóg, na którego skinienie wszystko stało się i trwa", Fizyka dla szkót narodowych, s. 536. W odniesieniu do Newtona, który sławił Boga w swoich Principiach, już to ukazując konieczność działania Boga jako swoistych postulatów warunkujących funkcjonowanie sformułowanego przez niego systemu fizyki, już to wnosząc o istnieniu i naturze Boga z Jego skutków działania w świecie zob. M. Heller, J. Życiński, Wszechświat - maszyna czy myśl?, s. 85-95. Por. D. Kubrin, Newton and the Cyclical Cosmos. Providence and the Mechanical Philosophy, "Journal of the History of Ideas", vol. 28, 1967, s. 325-346; J. Kierul, Izaak Newton. Bóg, światto i świat, Oficyna Wydawnicza Quadrivium, Wrocław 1996; E. Nowosad, Credo Izaaka Newtona. Chrześcijaństwo ireniczne, „Studia Theologica Varsaviensia”, vol. 25, 1987, nr 2, s. 149-177. Podobnie sądził twórca filozofii korpuskularnej R. Boyle: „Filozofia, której bronię, sięga do rzeczy czysto cielesnych; rozróżniając pomiędzy pierwszym źródłem rzeczy a następującym potem biegiem natury, uczy, że Bóg [...] ustalił owe reguły ruchu oraz porządek wśród rzeczy cielesnych, który my nazywamy prawami natury. Tak więc skoro Bóg niegdyś ukształtował istnienie wszechświata i ustanowił prawa ruchu, a wszystko wspomagane jest przez jego nieustanny udział i powszechną Opatrzność [...] zjawiska świata są fizycznie tworzone przez mechaniczne własności cząstek materii". R. Boyle, The Excellency and Grounds of the Mechanical Hypothesis, w: The Philosophical Works of the Honourable Robert Boyle, red. P. Shaw, t. 1, London 1725, s. 187. Cyt. za: A. C. Crombie, Nauka średniowieczna, t. 2, s. 387. 
Buba J., Józef Herman Osiński. Pierwszy elektryk polski, hutnik i chemik, w: idem, Pijarzy w kulturze dawnej Polski, Polska Prowincja XX Pijarów, Kraków 1982, s. 236-242.

Buffon G. L., De l'homme, wyd. M. Duchet, Maspero, Paris 1971.

Buffon G. L., Historie naturelle, t. 1-44, Paris 1749-1804.

Bugajak G., Problem naturalizmu w dialogu nauki i religii, w: Filozofia przyrody, red. S. Janeczek, A. Starościc, D. Dąbek, J. Herda, Wydawnictwo KUL, Lublin 2013, s. 301-320.

Butterfield H., Rodowód współczesnej nauki 1300-1800, przekł. H. Krahelska, PWN, Warszawa 1968.

Butterwick-Pawlikowski R., Między Oświeceniem a katolicyzmem, czyli o katolickim oświeceniu i oświeconym katolicyzmie, „Wiek Oświecenia”, t. 30, 2014, s. 15-17.

Chaunu P., Cywilizacja wieku oświecenia, PIW, Warszawa 1993.

Chróścikowski S., Fizyka doświadczeniami potwierdzona, Warszawa 1764.

Condillac É., CEuvres philosophiques de Condillac, t. 1, red. G. Le Roy, Presses universitaires de France, Paris 1947.

Crombie A. C., Nauka średniowieczna i poczatki nauki nowożytnej, t. 2, przekł. S. Łypacewicz, Instytut Wydawniczy „Pax”, Warszawa 1960.

Darowski R., Studia z filozofii jezuitów w Polsce XVII i XVIII wieku, Akademia Ignatianum - Wydawnictwo WAM, Kraków 1998.

Diderot D., Myśli filozoficzne, w: Wybór pism filozoficznych, przekł. J. Hartwig, J. Rogoziński, Państwowy Instytut Wydawniczy, Warszawa 1960.

Encyclopédie ou dictionnaire universel raisonné des sciences, des arts et des métiers, par une société de gens de lettres. Mis en ordre et publié par... [Denis] Diderot et quant à la partie mathématique par... ... [Jean le Rond] D'Alembert, t. 1-35, Paris 1751-1780; reprint F. Frommann Verlag, Stuttgart 1966-1995.

Essays on Aristotle's "De anima”, red. M. C. Nussbaum, O. Rorty, Clarendon Press, Oxford 1992.

Gut P., Radykalne Oświecenie i nowoczesność, w: Znaczenie filozofii Oświecenia. Człowiek wśród ludzi, red. B. Grabowska, A. Grzeliński, J. Żelazna, Wydawnictwo Naukowe UMK, Toruń 2016, s. 91-102.

Guyénot E., Les sciences de la vie aux XVII et XVIII siècles. L'idée d'évolution, A. Michel, Paris 1957.

Hajduk Z., Filozofia przyrody Isaaca Newtona, "Studia Philosophiae Christianae", R. 24, 1988, nr 2, s. 115-129.

Hajduk Z., Racjonalna rekonstrukcja filozofii przyrody Isaaca Newtona, w: Oblicza filozofii XVII wieku, red. S. Janeczek, Wydawnictwo KUL, Lublin 2008, s. 423-440.

Hall A. R., Rewolucja naukowa 1500-1800. Kształtowanie się nowożytnej postawy naukowej, przekł. T. Zembrzuski, Instytut Wydawniczy „Pax”, Warszawa 1966.

Heller M., Filozofia świata, Wydawnictwo „Znak”, Kraków 1992.

Heller M., Życiński J., Wszechświat-maszyna czy myśl?, Polskie Towarzystwo Teologiczne, Kraków 1988.

Hube M., Mechanika, Kraków 1792. 
Hube M., Wstęp do fizyki do szkót narodowych, Kraków 1783.

Israel J., A Revolution of the Mind. Radical Enlightenment and the Intellectual Origins of Modern Democracy, Princeton University Press, Princeton, NJ, 2009.

Israel J., Democratic Enlightenment. Philosophy, Revolution, and Human Rights, 1750-1790, Oxford University Press, Oxford 2011.

Janeczek S., Czym była oświeceniowa "philosophia recentiorum”, „Kwartalnik Filozoficzny", t. 26, 1998, nr 1, s. 115-128.

Janeczek S., Edukacja oświeceniowa a szkoła tradycyjna. Z dziejów kultury intelektualnej i filozoficznej, Wydawnictwo KUL, Lublin 2008.

Janeczek S., Elementy humanizmu renesansowego w szkole jezuickiej, w: Renesansowy ideat chrześcijanina, red. W. Sajdek, Wydawnictwo KUL, Lublin 2006, s. 299-333.

Janeczek S., Epistemologia w dydaktyce fizyki Komisji Edukacji Narodowej, „,Roczniki Filozoficzne", t. 50, 2002, nr 1, s. 203-262.

Janeczek S., Filozofia w "Wielkiej Encyklopedii Francuskiej”, w: Z badań nad filozofia XVII wieku, jej źródłami i kontynuacjami, red. H. Jakuszko, Lubelskie Towarzystwo Naukowe, Lublin 2013, s. 157-170.

Janeczek S., Geneza nowożytnego arystotelizmu chrześcijańskiego, w: Oblicza filozofii XVII wieku, red. S. Janeczek, Wydawnictwo KUL, Lublin 2008, s. 477-512.

Janeczek S., Historyczna czy filozoficzna koncepcja religii Hugona Kołtataja?, w: Mit - historia - kultura, red. J. Skoczyński, Wydawnictwo Akademickie UJ, Kraków 2012, s. 23-32.

Janeczek S., Ideały wychowawcze i dydaktyczne w szkolnictwie pijarskim a "oświecenie chrześcijańskie”. Próba syntezy, „Nasza Przeszłość”, t. 49, 1994, nr 82, s. $115-161$.

Janeczek S., Ideały wychowawcze w edukacji oświeceniowej (w perspektywie historii intelektualnej). Z dziejów Komisji Edukacji Narodowej, „Roczniki Kulturoznawcze", t. 6, 2015, nr 2, s. 5-37.

Janeczek S., Komisja Edukacji Narodowej a „Encyklopedia, albo słownik rozumowany nauk, sztuk i rzemiost", cz. 2: Wymiar dydaktyczny, "Zeszyty Naukowe KUL", t. 59, 2016, nr 2(234), s. 3-22.

Janeczek S., Logika czy epistemologia? Historycznofilozoficzne uwarunkowania nowożytnej koncepcji logiki, Wydawnictwo KUL, Lublin 2003.

Janeczek S., Od filozofii Boga do filozofii religii w dobie oświecenia, w: Filozofia a religia. Inspiracje - krytyka, red. S. Janeczek, A. Starościc, Wydawnictwo KUL, Lublin 2014, s. 85-108.

Janeczek S., Oświecenie chrześcijańskie. Z dziejów polskiej kultury filozoficznej, Redakcja Wydawnictw Katolickiego Uniwersytetu Lubelskiego, Lublin 1994.

Janeczek S., Oświeceniowa kultura naukowa w kontekście filozoficznym. Z dziejów Komisji Edukacji Narodowej (cz. 1-2), „Roczniki Filozoficzne”, t. 63, 2015, nr 4, s. 35-114.

Janeczek S., Przejawy refleksji metafizycznej w filozofii Étienne'a Bennota de Condillaca (1715-1780), w: Z dziejów filozoficznej refleksji nad człowiekiem. Księ- 
ga pamiatkowa ku czci Profesora Jana Czerkawskiego (1939-2007), Redakcja Wydawnictw KUL, Lublin 2007, s. 257-274.

Janeczek S., Prepozytywizm filozofii Jean le Rond d'Alemberta?, „Zeszyty Naukowe KUL", t. 55, 2012, nr 2(218), s. 3-24.

Janeczek S., Przyrodoznawstwo w polskim szkolnictwie kościelnym okresu oświecenia, „Roczniki Filozoficzne”, t. 41, 1993, nr 3, s. 87-109.

Janeczek S., Rola oświecenia chrześcijańskiego w kulturze wieku XVIII, „Kultura i Wartości", t. 15, 2015, s. 9-48.

Janeczek S., Szkoła jezuicka a szkoła renesansowa. Regres czy twórcza kontynuacja?, „Rocznik Wydziału Pedagogicznego Wyższej Szkoły Filozoficzno-Pedagogicznej Ignatianum w Krakowie", 2005, s. 191-208.

Janeczek S., Witalistyczno-mechanistyczna koncepcja życia w podręcznikach Komisji Edukacji Narodowej, w: Z potrzeby serca, red. Z. Krzyszowski i in., Instytut Wyższej Kultury Religijnej, Lublin 2004.

Janeczek S., Wspótczesna reforma nauki i szkolnictwa wyższego w perspektywie historycznej, "Communio", t. 33, 2013, nr 2(182), s. 116-139.

Janeczek S., Z badań nad przyrodoznawstwem w szkołach Komisji Edukacji Narodowej, w: Wierność rzeczywistości. Księga Pamiątkowa z okazji jubileuszu 50-lecia pracy naukowej na KUL O. prof. Mieczystawa A. Krapca, Polskie Towarzystwo Tomasza z Akwinu, Lublin 2001, s. 699-712.

Janeczek S., Z dziejów kultury naukowej. Koncepcja nauki Jean le Rond d'Alemberta, „Roczniki Kulturoznawcze", t. 4, 2013, nr 1, s. 59-92.

Kenntnisse von natürlichen Dingen zum Gebrauche der studierenden Jugend in den kaiserl. königl. Staaten, Wien 1781.

Kierul S., Izaak Newton. Bóg, światto i świat, Oficyna Wydawnicza Quadrivium, Wrocław 1996.

Kirkinen H., Les Origines de la conception moderne de l'homme-machine. Le problème de l'âme en France 1670-1715, Suomalainen Tiedeakatemia, Helsinki 1969.

Kluk K., Botanika dla szkół narodowych, Warszawa 1785.

Kluk K., Zwierzat domowych i dzikich, osobliwie krajowych, historii naturalnej poczatki $i$ gospodarstwo, t. 1, Warszawa 1779.

Kluk K., Czempiński P., Zoologia czyli zwierzętopismo dla szkót narodowych, Warszawa 1789.

Komisja Edukacji Narodowej (pisma Komisji i o Komisji). Wybór źródet, wyd. S. Tync, Zakład Narodowy im. Ossolińskich, Wrocław 1954.

Kopania J., Szkice kartezjańskie, Aureus, Kraków 2009.

Konarski S., Ustawy szkolne, przekł. W. Germain, M. Arct, Kraków 1925.

Krokiewicz A., Zarys filozofii greckiej, Aletheia, Warszawa 2000.

Kubrin D., Newton and the Cyclical Cosmos. Providence and the Mechanical Philosophy, ,Journal of the History of Ideas", vol. 28, 1967, s. 325-346.

Linnæus C., Systema naturae per regna tria naturae secundum classes, ordines, genera, species cum characteribus, differentiis, synonymis, locis, t. 1, Vindobonae 1767.

Lovejoy A. O., Wielki łańcuch bytu. Studium z dziejów idei, przekł. A. Przybysławski, „KR”, Warszawa 1999. 
Lubieniecka J., Towarzystwo do Ksiag Elementarnych, Nasza Księgarnia, Warszawa 1960.

Macquer P.-J., Dictionnaire portatif des arts et métiers (contenant en abrégé l'histoire, la description et la police des arts et métiers, des fabriques et manufactures de France et des pays etrangers, t. 1-2, Paris 1766.

Macquer P.-J., Élémens de chymie-pratique, contenant la description des opérations fondamentales de la chymie, avec des explications $\mathcal{E}$ des remarques sur chaque opération, t. 1-2, Paris 1751; idem jako: Elements of the Theory and Practice of chymistry, przekł. A. Reid, Edinburgh 1768.

Macquer P.-J., Élémens de chymie-théorique, Paris 1749.

Majorek C., Ksiażki szkolne Komisji Edukacji Narodowej, Wydawnictwa Szkolne i Pedagogiczne, Warszawa 1975.

Mickiewicz J., Układ lekcji w Akademii Wileńskiej na r. 1782, Wilno 1781.

Miodoński L., Całość jako paradygmat rozumienia świata w myśli niemieckiej przełomu romantycznego, Oficyna Wydawnicza Arboretum, Wrocław 2001.

Musschenbroek van P., Dissertatio experimentalis de magnete, Vienna 1754.

Musschenbroek van P., Institutiones physicae, Lugduni Batavorum 1748.

Musschenbroek van P., Introductio ad philosophiam naturalem, t. 1-2, Lugduni 1762.

Musschenbroek van P., Physicae experimentalis, et geometricae, magnitudinae terrae, cohaerentia corporum firmorum disserationes; ut et ephemerides meteorologicae ultraiectinae, Lugduni Batavorom 1729.

Nollet J. A., Leçons de physique expérimentale, t. 1-6, Paris 1743-1746.

Nowosad E., Credo Izaaka Newtona. Chrześcijaństwo ireniczne, „Studia Theologica Varsaviensia", t. 25, 1987, nr 2, s. 149-177.

Osiński J. H., Fizyka doświadczeniami potwierdzona, Warszawa 1777.

Piechowiak M., Aksjologiczne podstawy Karty praw podstawowych Unii Europejskiej, "Studia Prawnicze”, 2003, nr 1(155), s. 5-29.

Pluche de N.-A., Histoire du ciel où l'on recherche l'origine de l'dolâtrie et les méprises de la philosophie sur la formation et sur les influences des corps célestes, t. 1-2, Paris 1711-1740.

Pluche de N.-A., Le spectacle de la nature, ou Entretiens sur les particularités de l'histoire naturelle, qui ont paru les plus propres à rendre les jeunes-gens curieux, $\mathcal{E}$ à leur former l'esprit, t. 1-8, Paris 1732-1752.

Protokoty Towarzystwa do Ksiag Elementarnych, wyd. T. Wierzbowski, Kasa im. J. Mianowskiego, Warszawa 1908.

Roger J., Les sciences de la vie dans la pensée française du XVIIIe siècle, Michel, Paris 1993.

Sagan D., Teoria inteligentnego projektu - argumenty za i przeciw, w: Filozofia przyrody, red. S. Janeczek, A. Starościc, D. Dąbek, J. Herda, Wydawnictwo KUL, Lublin 2013, s. 335-383.

Schaw P., Leçons de Chymie. Propres à perfectionner la physique, le commerce et les arts, przekł. M.-G.-Ch. Thiroux d'Arconville, Paris 1759; idem jako: Chemical lectures publicly read at London, in the years 1731, and 1732, and at Scarborough, in 1733, for the improvement of arts, trades, and natural philosophy, London 1755. 
Skarbek J., Pojęcia wstępne fizyki Antoniego Wiśniewskiego, „Studia i Materiały z Dziejów Nauki Polskiej" 1959, ser. A, nr 3, s. 181-203.

Skrzypek M., Filozofia Diderota, Wydawnictwo IFiS PAN, Warszawa 1996.

Swieżawski S., Albertyńsko-tomistyczna a kartezjańska koncepcja człowieka, "Przegląd Filozoficzny”, t. 43, 1947, nr 1-4, s. 87-114.

Szybiak I., Szkolnictwo Komisji Edukacji Narodowej w Wielkim Księstwie Litewskim, Zakład Narodowy im. Ossolińskich, Wrocław 1973.

Śmierzchalski Z., Fizyka doświadczalna jako dziedzina filozofii w okresie oświecenia w Polsce na przykładzie dzieł Józefa Rogalińskiego (1728-1802), Wydział Filozoficzny Towarzystwa Jezusowego, Kraków 1998.

Ustawodawstwo szkolne za czasów Komisji Edukacji Narodowej. Rozporządzenia, ustawy pedagogiczne i organizacyjne (1773-1793), wyd. J. Lewicki, M. Arct, Kraków 1925.

Valmont de Bomare J.-Ch., Dictionnaire raisonné d'histoire naturelle, Paris 1764.

Wiśniewski A., Propositiones philosophicae, ex illustribus veterum recentiorumque philosophorum placitis depromptae, Varsaviae 1752.

Wójcik Z. J., Udział OO. pijarów w rozwoju przyrodoznawstwa w Polsce doby Oświecenia, w: Wkład pijarów do nauki i kultury w Polsce XVII-XIX wieku, red. I. Stasiewicz-Jasiukowa, Zakład Historii Nauk Społecznych IHNOiT PAN, Warszawa 1993, s. 219-237.

Wypisy z autorów klasycznych do nauk w szkołach narodowych stosowane na kl. I-III, Warszawa 1777-1780.

\section{Streszczenie}

\section{Kontekst filozoficzny dydaktyki przyrodoznawstwa w szkołach Komisji Edukacji Narodowej}

W wieku XVIII szkołę humanistyczną zwieńczoną kursem filozofii, traktowanym jako synonim wiedzy realnej, zastępuje stopniowo oświata eksponująca wage kształcenia matematyczno-przyrodniczego, które wchodzi bądź to w skład kursu filozofii, bądź też go zastępuje. To drugie podejście ujawniło się w szkołach KEN, gdyż wbrew praktyce dominującej w szkole europejskiej usunięto praktycznie dydaktykę filozofii z kształcenia uniwersyteckiego. Natomiast w oświeceniowym szkolnictwie europejskim systemowo pojęty nowożytny arystotelizm chrześcijański zastąpiła philosophia recentiorum, która od połowy wieku XVIII eklektycznie asymilowała nowożytną kulturę filozoficzną i naukową (przyrodniczą). W tym kontekście także nieśmiało jeszcze funkcjonuje samodzielne przyrodoznawstwo, które mimo presji fenomenalizmu stymulowanego przez nowożytny empiryzm zachowa elementy podejścia filozoficzno-religijnego. Ta tradycyjna perspektywa wyrazi się w formie elementów substancjalizmu, a w odniesieniu do przyrody ożywionej także w formie zachowania kategorii duszy, właściwej nie tylko człowiekowi, ale także zwierzętom. Jeśli więc w postulatach programowych KEN ujawniły się przejawy swoistego prepozytywi- 
zmu, to przecież podręczniki wykorzystywane w tym systemie oświaty podtrzymały bardziej tradycyjna, eklektyczną formę przyrodoznawstwa, zresztą w sposób typowy dla ówczesnego szkolnictwa europejskiego.

\section{Słowa kluczowe}

historia filozofii, historia nauki, historia szkolnictwa, epoka oświecenia, Rzeczpospolita Obojga Narodów, Komisja Edukacji Narodowej

\section{Summary}

\section{The Philosophical Context of the Didactics of Philosophy of Nature in the Schools of the Commission of National Education}

The humanistic school completed with a course of philosophy, treated as synonymous with real knowledge, is in the 18th century gradually replaced by an education that stresses the importance of teaching mathematics and natural science; the latter elements become either parts of the course of philosophy, or substitute it. The latter approach appeared in the schools of the Commission of National Education, for contrary to the practice dominant in the European school the didactic of philosophy was practically eliminated from university education. Now in the enlightenment European schooling modern Christian Aristotelianism, comprehended as a system, was replaced by philosophia recentiorum, a philosophy that from the 1750s onwards had eclectically assimilated modern philosophical and scientific (natural) culture. In this context natural science still functions within certain modest limits; despite the pressure of phenomenalism stimulated by modern empiricism it manages to retain some elements of its philosophical and religious approach. This traditional perspective is then manifested in the form of some elements of substantialism, and in relation to animate nature also in the form in which the category of the soul is preserved, the soul that is proper not only to man but also to animals. Therefore even if in the curriculum postulates of the Commission of National Education there were some manifestations of peculiar pre-positivism, the manuals used in this system of education sustained a more traditional and eclectic form natural philosophy, indeed in a manner typical of the then European schooling.

\section{Keywords}

history of philosophy, history of education, history of schooling, the age of the Enlightenment, the Polish and Lithuanian Commonwealth, the Commission of National Education 